\title{
Pengendalian Folikulogenesis Ovarium dengan Pemberian Ekstrak Biji Kapas
}

\section{Folliculogenesis Control in Ovarian with the Cottonseed Extract}

\author{
Siska Adelya Ramadhani ${ }^{1}$, Iman Supriatna ${ }^{1,2}$, Ni Wayan Kurniani Karja ${ }^{2}$, Adi Winarto ${ }^{3}$ \\ ${ }^{1}$ Program Studi Biologi Reproduksi, Sekolah Pascasarjana, Institut Pertanian Bogor \\ ${ }^{2}$ Departemen Klinik Reproduksi dan Patologi, Fakultas Kedokteran Hewan, Institut Pertanian Bogor \\ ${ }^{3}$ Departemen Anatomi, Fisiologi dan Farmakologi, Fakultas Kedokteran Hewan, Institut Pertanian Bogor \\ Jl. Agatis Kampus IPB Dramaga Bogor, 16680 \\ Email : iman_sprtn@yahoo.com
}

\begin{abstract}
Gosipol is a substances contained in extracted cotton seed which is thought to have the antifertility ability therefore it is often used as a herbal contraceptive. The aim of this study were to assess the folliculogenesis in mice after administrated with cottonseed extract. 60 female mice strain DDY which was 14-15 weeks old and 30-35 g body weight were divided into five groups and given cottonseed extract each $0 ; 1,5 ; 2,1$ and 2,7 g/kg BW for $5,10,15,24$, and $24+10$ days (without cottonseed treatment). At the end of the treatment period, mice was euthanasia to observe follicular development histomorphology (each three mice of each treatment). Mice estrous status were evaluated based on the description of the vaginal smear cells with Giemsa staining. The results showed that the number of developing follicles was low $(\mathrm{P}<0.05)$ compared with control after 5 days cottonseed extract administration at dose $2,7 \mathrm{~g} / \mathrm{kg}$ BW that were $23 \pm 3,6$. At dose 1,5 and $2,1 \mathrm{~g} / \mathrm{kg}$ BW the number of follicles was low after 24 days that were $25 \pm 10,4$ and $27 \pm 3,5$. Recovery effects of follicle number after cottonseed extract administration for 24 days was the best at a dose of $1,5 \mathrm{~g} / \mathrm{kg}$ BW. Prolonge of estrous cycle occured in mice which were administrated the cottonseed extract of at all dose treatment. In conclusion, although the decrease in the number of developing follicles and prolonge of estrous cycles occurred after cottonseed extract administration, but these effects are reversible after the administration ended.
\end{abstract}

Keywords: antifertility, cotton seed, folliculogenesis, gossypol

\begin{abstract}
Abstrak
Gosipol adalah zat yang terkandung dalam ekstrak biji kapas dan diduga mempunyai kemampuan antifertilitas sehingga sering digunakan sebagai bahan herbal kontrasepsi. Penelitian ini bertujuan mengkaji gambaran folikulogenesis pada mencit yang diberi ekstrak biji kapas. Sebanyak 60 ekor induk mencit betina strain DDY berumur 14-15 minggu dengan bobot badan 30-35 g dibagi menjadi 4 kelompok dan diberi ekstrak biji kapas masing-masing $0 ; 1,5 ; 2,1$ dan 2,7 g/kg BB selama 5, 10, 15, 24 dan $24+10$ hari (tanpa pemberian ekstrak biji kapas). Pada setiap akhir waktu pengamatan, mencit di-euthanasia untuk mengamati histomorfologi perkembangan folikel (masing-masing tiga ekor dari tiap perlakuan). Status estrus mencit dievaluasi berdasarkan gambaran sel dari ulas vagina dengan pewarnaan Giemsa. Hasil penelitian menunjukkan bahwa jumlah folikel rendah $(\mathrm{P}<0,05)$ dibandingkan dengan kontrol setelah 5 hari pemberian ekstrak biji kapas dengan dosis 2,7 g/kg BB yaitu $23 \pm$ 3,6. Pada dosis 1,5 dan $2,1 \mathrm{~g} / \mathrm{kg}$ BB jumlah folikel menjadi rendah setelah 24 hari yaitu $25 \pm 10,4 ; 27 \pm 3,5$. Efek pemulihan jumlah folikel setelah pemberian ekstrak biji kapas selama 24 hari paling baik pada dosis $1,5 \mathrm{~g} / \mathrm{kg}$ BB. Pemanjangan siklus estrus terjadi pada mencit yang diberi ekstrak bji kapas pada semua dosis perlakuan. Berdasarkan hasil tersebut dapat disimpulkan bahwa walaupun terjadi penurunan jumlah folikel yang berkembang dan terjadi pemanjangan siklus estrus setelah pemberian ekstrak biji kapas, tetapi efek tersebut bersifat reversible setelah pemberian dihentikan.
\end{abstract}

Kata kunci: antifertilitas, biji kapas, folikulogenesis, gosipol 


\section{Pendahuluan}

Fertilitas merupakan kemampuan organ reproduksi untuk bekerja optimal dalam menjalankan fungsi fertilisasi. Pada betina, fertilitas berkaitan erat dengan folikulogenesis yaitu proses pertumbuhan dan perkembangan folikel yang terjadi di ovarium (Leung dan Adashi, 2004). Beberapa faktor dapat memengaruhi folikulogenesis seperti integrasi sinyal ekstraovarian dan intrafolikuler (Webb et al, 2003), endokrinologi (Paris et al, 2009), perkembangan gonad, serta kondisi nutrisi (Chavatte-Palmer et al, 2014). Oleh karena itu, pengendalian folikulogenesis dapat dijadikan sebagai salah satu cara untuk mencegah terjadinya fertilisasi dan dapat digunakan sebagai salah satu metode kontrasepsi.

Banyak zat tumbuhan telah dipercaya mempunyai aktivitas sebagai antifertilitas sehingga sering digunakan sebagai bahan kontrasepsi. Salah satu tumbuhan yang mengandung zat antifertilitas adalah tanaman kapas karena memiliki kandungan zat aktif berupa gosipol (Singla dan Garg, 2013). Banyak penelitian telah dilakukan untuk mengkaji pengaruh pemberian ekstrak biji kapas untuk mengetahui pengaruhnya terhadap reproduksi pada hewan model. Pemberian gosipol secara oral sebanyak $30 \mathrm{mg} / \mathrm{kg}$ BB setiap hari selama lima minggu mampu menurunkan fertilitas (Singla dan Garg, 2013) tikus jantan tanpa menurunkan libido (Hadley et al, 1981). Pemberian gosipol pada hewan jantan juga tidak memengaruhi laju pertumbuhan tikus, bobot testis, dan kelenjar aksesori seksual (White et al, 1988), sedangkan pada betina, pemberian $25 \mathrm{mg} / \mathrm{kg}$ gosipol pada tikus betina menyebabkan ketidakteraturan siklus estrus lebih dari 75\% (Lin et al, 1985) serta memperpanjang durasi siklus estrus (Lagerlof dan Tone, 1985). Gosipol yang diinjeksikan secara intrauteri mampu memengaruhi jumlah ovum yang terfertilisasi, implantasi embrio, perkembangan embrio, dan jumlah anak (Lin et al, 1994a). Efek tersebut bersifat reversible apabila pemberian gosipol dihentikan (Gadelha et al, 2014a). Penelitian pada sapi dilaporkan bahwa gosipol yang dicampur dalam pakan mengakibatkan folikel besar $(>5 \mathrm{~mm}$ ) pada ovarium relatif sedikit dibandingkan dengan yang diberi makan kedelai (Gadelha et al, 2014a). Walaupun sudah banyak penelitian yang dilakukan untuk mengetahui pengaruh pemberian ekstrak biji kapas pada hewan coba, tetapi belum ditemukan laporan tentang pengaruh pemberian ekstrak biji kapas terhadap gambaran folikulogenesis. Oleh karena itu penelitian ini bertujuan mengkaji pengendalian folikulogenesis ovarium dan status siklus estrus mencit setelah pemberian ekstrak biji kapas.

\section{Materi dan Metode}

\section{Ekstraksi Biji Kapas}

Biji kapas diperoleh dari Balai Penelitian Tanaman Pemanis dan Serat (Balittas), Malang Provinsi Jawa Timur yang dikoleksi dari tanaman kapas umur 5 bulan. Biji kapas kering digerus kemudian disaring untuk mendapatkan serbuk simplisia. Ekstraksi dilakukan dengan metode maserasi (perendaman) yang dilanjutkan dengan evaporasi pada suhu $68{ }^{\circ} \mathrm{C}$ (Chandrashekar et al, 2013).

\section{Kajian pemberian ekstrak biji kapas terhadap gambaran folikulogenesis dengan histomorfologi}

Hewan yang digunakan adalah 60 ekor mencit induk (Mus musculus L. DDY) umur 14 15 minggu dengan rata-rata berat badan $30-35 \mathrm{~g}$. 
Mencit diadaptasikan selama dua minggu dan diberi obat cacing (Combantrin $^{\circledR}$ ) 1,4 mg/kg BB. Mencit dipelihara secara kelompok di rumah sakit hewan pendidikan IPB (lima ekor mencit perkandang). Selama pemeliharaan mencit diberi $5 \mathrm{~g}$ pakan perhari berupa pellet (Indo Feed ${ }^{\circledR}$ dan air minum diberikan secara ad libitum. Siklus pencahayaan diatur terang (06.00 - 18.00) dan gelap (18.00 - 6.00). Penggunaan hewan coba dalam penelitian ini sudah mendapatkan persetujuan dari Komisi Etik Hewan IPB nomor 15 -2016 IPB.

Mencit dibagi menjadi empat kelompok (15 ekor setiap perlakuan) dan diberi ekstrak biji kapas dengan dosis $0 ; 1,5 ; 2,1$ dan $2,7 \mathrm{~g} / \mathrm{kg}$ BB selama 5 hari (D0-5; D1,5-5; D2,1-5 dan D2,7-5), 10 hari (D010; D1,5-10; D2,1-10 dan D2,7-10), 15 hari (D0-15; D1,5-15; D2,1-15 dan D2,7-15), dan 24 hari (D024; D1,5-24; D2,1-24 dan D2,7-24). Ekstrak biji kapas diberikan secara oral menggunakan syringe sonde dengan pelarut carboxy methyl cellulose (CMC) 0,2\% pada fase proestrus dan didefinisikan sebagai hari pertama (H1) pemberian ekstrak biji kapas. Pada setiap akhir periode pemberian ekstrak biji kapas, mencit di-euthanasia untuk mengamati folikulogenesis berdasarkan gambaran histomorfologi perkembangan folikel (masingmasing 3 ekor dari tiap perlakuan). Sedangkan untuk sampel reversible diambil 10 hari setelah pemberian ekstrak biji kapas selama 24 hari dihentikan.

Pengamatan histomorfologi dilakukan dengan euthanasia mencit dengan metode extinguish secara intracardial setelah dianasthesi dengan ketamin dan xylazin. Preparat histologi ovarium diwarnai dengan hematoxylin-eosin (HE). Folikulogenesis diamati dengan melihat jumlah folikel primer, sekunder, dan tersier (Myers et al, 2004) sesuai dengan klasifikasi folikel pada ovarium mencit menurut Peters (1969). Folikel primordial ditandai dengan diameter oosit $<$ $20 \mu \mathrm{m}$ dan oosit mulai dikelilingi selapis sel epitel pipih. Folikel primer ditandai dengan diameter oosit $>20 \mu \mathrm{m}$ dan oosit dikelilingi selapis sel epitel kuboid (sel granulosa) dan zona pelusida. Folikel sekunder ditandai dengan diameter oosit $70 \mu \mathrm{m}$ dan oosit dikelilingi beberapa lapis sel granulosa, zona pelusida, sudah mulai ada antrum yang tersebar pada lapisan granulosa. Folikel tersier ditandai dengan diameter oosit $70 \mu \mathrm{m}$ dan oosit dikelilingi beberapa lapis sel granulosa, zona pelusida, antrum yang tersebar berkembang menjadi satu kesatuan antrum.

\section{Kajian siklus estrus mencit berdasarkan gambaran sel ulas vagina dengan pewarnaan Giemsa}

Pengamatan terhadap siklus estrus dilakukan mulai dari hari pertama (H1) sampai hari pengambilan ovarium yaitu setelah hari ke-5,10, 15, 24 dan 34 pemberian estrak biji kapas. Ulas vagina dilakukan dengan bantuan cottonbud dan $\mathrm{NaCl}$ fisiologis yang diulas 3-5 kali selanjutnya diulas pada gelas obyek, kemudian diwarnai dengan Giemsa, prerapat diamati di bawah mikroskop (Olympus CX31) dengan perbesaran obyektif 10-40 kali. Pada ulas vagina ditentukan fase yang sedang dialami hewan coba melalui tipe sel, proporsi masing-masing sel, dan keberadaan leukosit.

\section{Analisis Data}

Penelitian ini menggunakan rancangan acak lengkap (RAL) pola faktorial dengan 2 faktor perlakuan yaitu lama waktu pemberian dan dosis. Data berupa jumlah folikel berkembang, persentase jumlah folikel primer, sekunder, dan tersier dianalisis dengan analisis varian (ANOVA). Perbedaan hasil 
ANOVA dilanjutkan dengan Duncan multiple range test (DMRT) pada taraf 5\%. Data diolah menggunakan program SPSS versi 16.

\section{Hasil dan Pembahasan}

Hasil pengamatan mikroskopis berdasarkan histologi dari ovarium mencit dalam penelitian ini didapatkan bahwa pada ovarium terdapat folikel yang beragam. Keragaman folikel dapat dilihat dari hasil histologi ovarium (Gambar 1).

Adanya keragaman folikel tersebut menunjukkan bahwa terjadi perkembangan folikel di dalam ovarium. Folikel-folikel yang ditemukan adalah folikel primordial, primer, sekunder, dan tersier. Folikel primordial cenderung ditemukan di daerah korteks ovarium dan terdapat oosit yang dikelilingi oleh satu lapis sel granulosa lebih pipih dari sel kuboid. Folikel primer (Gambar 1a) juga ditemukan di daerah korteks ovarium yang ditandai dengan oosit dan zona pelusida yang dikelilingi oleh satu lapis sel granulosa kuboid dan satu lapisan luar sel pipih. Folikel sekunder (Gambar 1b) berada di seluruh ovarium yang ditandai dengan oosit dikelilingi oleh beberapa lapis sel granulosa kuboid. Folikel tersier (Gambar 1c) juga berada di seluruh ovarium yang ditandai dengan oosit dikelilingi oleh beberapa lapis sel granulosa kuboid dan berkembangnya antrum. Selain itu juga ditemukan corpus luteum (Gambar 1a) yang menunjukkan bahwa oosit telah diovulasikan. Pengelompokan folikel pada penelitian ini mengacu pada laporan Scudamore (2014) yang mengelompokkan folikel ovarium berdasarkan penampilan morfologi lapisan sel granulosa seperti yang disajikan pada Gambar 2.

Pertumbuhan dan perkembangan folikel mencakup pertumbuhan oosit, proliferasi sel granulosa, pembentukan antrum, aktivasi reseptor follicle stimulating hormone (FSH) dan luteinizing hormone (LH), pembentukan hormon estrogen hingga oosit diovulasikan (Leung dan Adashi, 2004). Secara histomorfologi terlihat bahwa pada saat pertumbuhan terjadi pertambahan ukuran folikel dari folikel primordial, folikel primer, dan folikel sekunder.

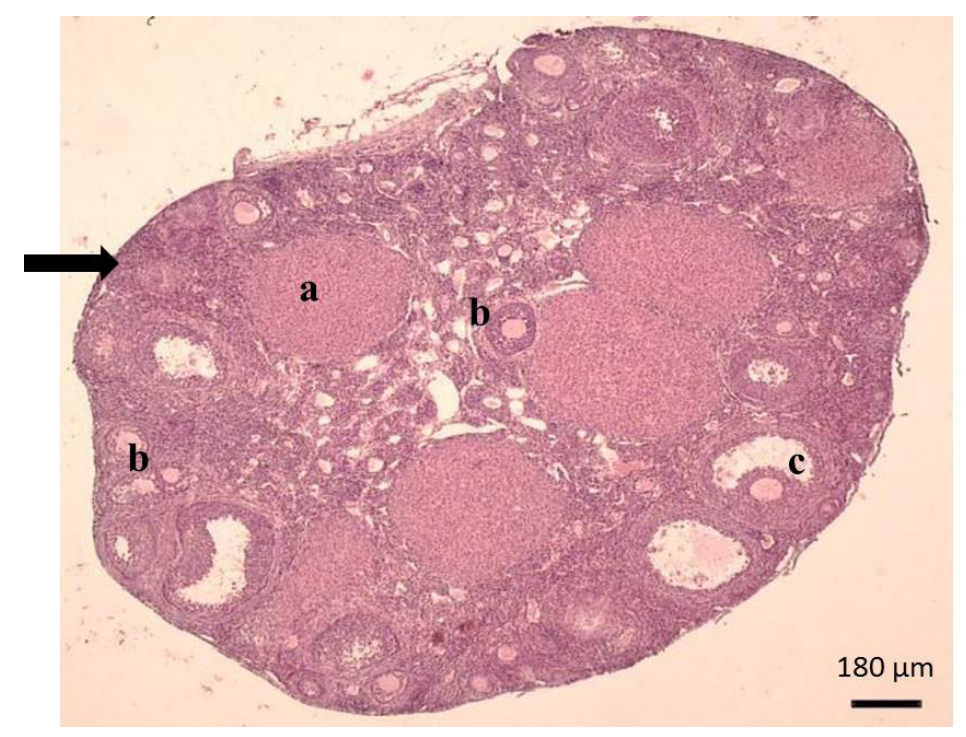

Gambar 1. Ovarium mencit (kontrol). Corpus luteum (a), folikel sekunder (b), folikel tersier (c), korteks ovarium $(\rightarrow)$. 

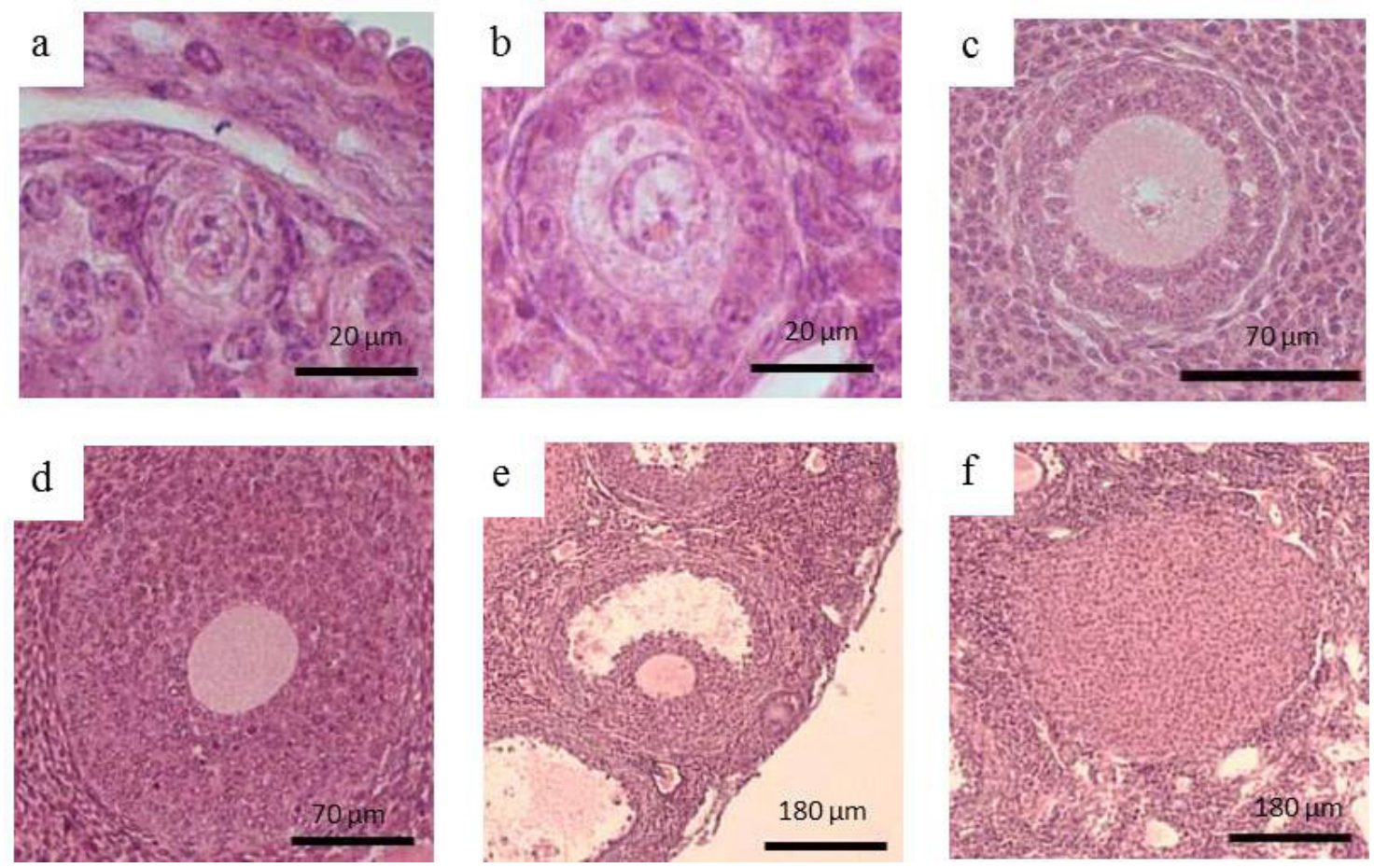

Gambar 2. Perkembangan folikel ovarium. Folikel primordial (a), folikel primer (b), folikel sekunder (c dan d), folikel tersier (e), corpus luteum (f).

Folikulogenesis dimulai dari perekrutan folikel primordial dalam jumlah banyak yang dijumpai pada bagian korteks ovarium. Perekrutan tersebut diatur oleh tekanan jaringan dalam stroma pada korteks ovarium. Kepadatan stroma menurun secara bertahap dari korteks hingga bagian medula (Woodruff dan Shea, 2011). Folikulogenesis dimulai saat folikel primordial menuju arah medula yang lebih lunak. Hal tersebut memicu selesainya istirahat meiosis oosit dalam folikel primordial (Silber, 2015) dan berkembang menjadi folikel primer kemudian folikel sekunder. Folikel sekunder mulai terjadi pembentukan antral kecil dan tersebar, selanjutnya antral menyatu sehingga terbentuk folikel tersier. Pada masa pembentukan antrum terjadi dinamika folikel antral yang terdiri atas perekrutan, seleksi, dominan dan atresi. Selama perkembangan jumlah folikel terus berkurang hingga mencapai folikel preovulasi (Senger, 2005).
Tabel 1 menyajikan jumlah total folikel berkembang dalam ovarium setelah pemberian ekstrak biji kapas. Jumlah folikel berkembang setelah pemberian ekstrak biji kapas selama 5, 10, dan 15 hari menunjukkan bahwa mencit yang diberi ekstrak biji kapas dengan dosis $2,7 \mathrm{~g} / \mathrm{kg}$ BB memiliki jumlah folikel lebih rendah $(\mathrm{P}<0,05)$ dibandingkan dengan dosis 1,5 dan 2,1 g/kg BB. Efektivitas ekstrak biji kapas dengan dosis $2,7 \mathrm{~g} / \mathrm{kg}$ BB sama pada pemberian 5, 10, 15, dan 24 hari. Berdasarkan hasil tersebut diketahui bahwa pemberian ektrak biji kapas paling efektif selama 5 hari dengan dosis $2,7 \mathrm{~g} / \mathrm{kg}$ BB. Pemberian ekstrak biji kapas selama 24 hari menunjukkan jumlah folikel berkembang rendah $(\mathrm{P}<0,05)$ pada semua dosis perlakuan dibandingkan dengan kelompok pemberian ekstrak biji kapas selama 5, 10, dan 15 hari. Perbedaan jumlah folikel berkembang dapat disebabkan lama waktu pemberian dan dosis yang diberikan (Camara et al, 2015; Sirard et al, 2006). 
Tabel 1. Jumlah folikel berkembang pada mencit setelah pemberin ekstrak biji kapas

\begin{tabular}{cllll}
\hline Waktu pemberian & Kontrol & $1,5 \mathrm{~g} / \mathrm{kg} \mathrm{BB}$ & $2,1 \mathrm{~g} / \mathrm{kg} \mathrm{BB}$ & $2,7 \mathrm{~g} / \mathrm{kg} \mathrm{BB}$ \\
\hline 5 hari & $24 \pm 4,5^{\text {de }}$ & $33 \pm 10,4^{\text {bcde }}$ & $42 \pm 10,0^{\text {abc }}$ & $23 \pm 3,6^{\text {de }}$ \\
10 hari & $19 \pm 8,5^{\mathrm{e}}$ & $36 \pm 4,5^{\text {bcde }}$ & $31 \pm 4,9^{\text {bcde }}$ & $23 \pm 5,0^{\text {de }}$ \\
15 hari & $33 \pm 7,4^{\text {bcde }}$ & $30 \pm 12,7^{\text {bcde }}$ & $37 \pm 12,5^{\text {bcd }}$ & $19 \pm 12,4^{\text {e }}$ \\
24 hari & $34 \pm 12,3^{\text {bcde }}$ & $25 \pm 10,4^{\text {de }}$ & $27 \pm 3,5^{\text {cde }}$ & $25 \pm 10,1^{\text {de }}$ \\
34 hari & $44 \pm 7,6^{\text {ab }}$ & $53 \pm 10,8^{\text {a }}$ & $29 \pm 6,2^{\text {bcde }}$ & $36 \pm 6,0^{\text {bcde }}$ \\
\hline
\end{tabular}

Keterangan: huruf kecil yang berbeda pada setiap baris di antara kelompok perlakuan di atas menunjukkan perbedaan nyata $(\mathrm{P}<0,05)$

Penurunan jumlah folikel diduga disebabkan oleh folikel yang banyak mengalami atresia sehingga hanya sedikit yang berkembang (Camara et al, 2015). Gadelha et al, (2014a) juga melaporkan bahwa pemberian gosipol secara subkutan dengan dosis $25 \mathrm{mg} / \mathrm{kg} /$ hari juga menyebabkan banyak folikel yang mengalami atresia. Atresia pada folikel besar akan menyebabkan kerusakan pada lapisan kumulus yang akan mengakibatkan gangguan perkembangan embrio (Sirard et al, 2006). Selain itu folikel atresia akan menghasilkan oosit yang sulit menyelesaikan metafase II (Nasim et al., 1995). Gosipol merusak kompetensi meiosis yang diperoleh pada saat perkembangan folikel. Hal ini berdasarkan pernyataan Cecconi (2002) bahwa kemampuan meneruskan meiosis diperoleh bersamaan dengan pembentukan antrum. Pemberian ekstrak biji kapas walaupun memengaruhi ovarium tetapi tidak menyebabkan perubahan berat badan yang mengindikasikan tandatanda toksisitas. Hasil ini sesuai dengan penelitian pada domba yang diteliti oleh Camara et al. (2015).

Penghentian pemberian ekstrak biji kapas selama 10 hari menunjukkan jumlah folikel berkembang mengalami peningkatan $(\mathrm{P}<0,05)$ dibandingkan dengan jumlah folikel berkembang setelah pemberian selama 24 hari. Pada dosis kontrol (0 g/kg BB) dan 1,5 g/kg BB menunjukkan jumlah yang lebih tinggi $(\mathrm{P}<0,05)$ dibandingkan dengan dosis 2,1 dan 2,7 g/kg BB. Berdasarkan hal tersebut diketahui bahwa terjadi pemulihan ovarium yang dilihat dari jumlah folikel berkembang setelah penghentian pemberian ekstrak terjadi hingga dosis $2,7 \mathrm{~g} / \mathrm{kg}$ BB. Efek pemulihan tersebut paling baik terlihat setelah penghentian pemberian ekstrak biji kapas pada dosis paling rendah yaitu $1,5 \mathrm{~g} / \mathrm{kg}$ BB.

Data pada Gambar 3 menunjukkan masingmasing populasi folikel primer (3a), sekunder (3b) dan tersier (3c). Persentase populasi folikel primer setelah pemberian ekstrak biji kapas selama 15 dan 24 hari lebih rendah $(\mathrm{P}<0,05)$ dibandingkan dengan 5 dan 10 hari. Jumlah folikel primer setelah pemberian ekstrak biji kapas selama 15 hari dengan dosis 2,7 $\mathrm{g} / \mathrm{kg}$ BB memiliki persentase jumlah folikel yang sama dengan pemberian ekstrak biji kapas selama 24 hari dengan dosis 2,1 dan 2,7 g/kg BB. Penghentian pemberian ekstrak selama 10 hari menunjukkan terjadi peningkatan jumlah folikel primer pada semua dosis perlakuan.

Persentase populasi folikel sekunder dan tersier belum bisa diduga karena jumlahnya yang fluktuatif $(\mathrm{P}<0,05)$ antara kelompok kontrol dan perlakuan. Hasil pengamatan tersebut berbeda dengan penelitian pada jumlah folikel besar pada sapi yang menerima $5 \mathrm{~g}$ gosipol per hari yang mengalami penurunan kuantitas (Randel et al, 1996). Keberadaan folikel tersier tidak jelas berubah 


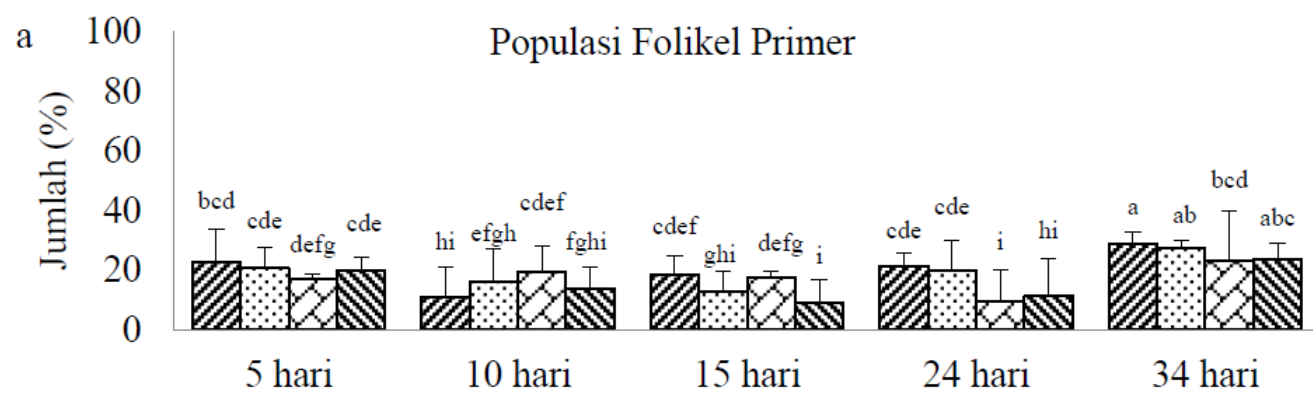

$\mathrm{b}$

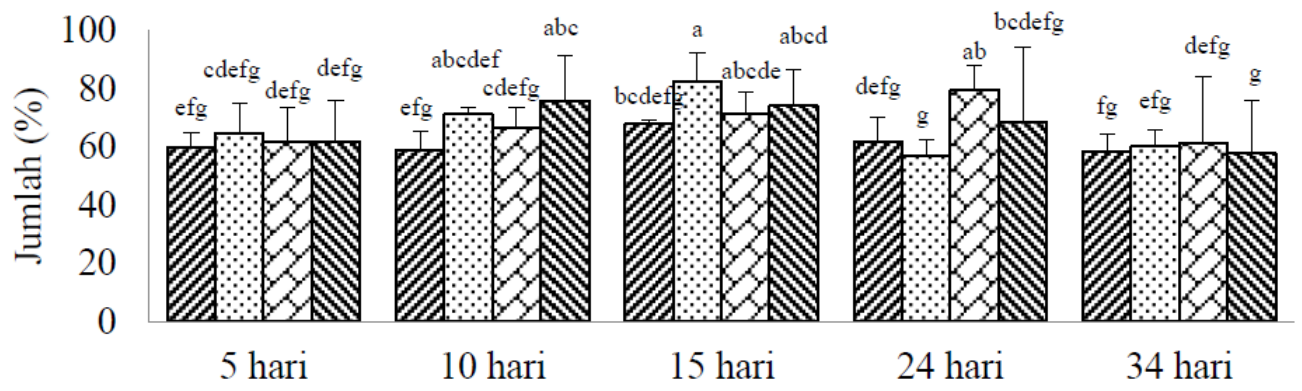

Gambar 3. Rata-rata jumlah folikel pada potongan histologi setelah pemberian ekstrak biji kapas. Folikel berkembang (a), primer (b), sekunder (c), dan tersier (d).

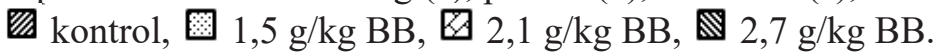

Keterangan: huruf kecil yang berbeda pada setiap histogram di antara kelompok perlakuan di atas menunjukkan perbedaan nyata $(\mathrm{P}<0,05)$

dari jumlahnya akibat pemberian ekstrak biji kapas namun pada perluasan perkembangan kumulus yang menjadi lapisan oosit pada folikel besar mengalami hambatan karena pemberian gosipol (Lin et al, 1994b).

Data pada Gambar 3 memperlihatkan folikel primer ditemukan dalam jumlah lebih sedikit dibandingkan folikel sekunder setelah pemberian ekstrak biji kapas. Hal tersebut menyebabkan jumlah folikel yang direkrut dan diseleksi untuk menjadi folikel dominan berkurang. Penurunan tersebut berdampak pada jumlah ovulasi selanjutnya. Folikel sekunder setelah pemberian ekstrak biji kapas masih banyak ditemukan, namun pada proses perkembangan menjadi folikel tersier tidak banyak folikel yang mampu terus berkembang. Folikel yang telah berkembang menjadi folikel sekunder kemungkinan telah atresi (Camara et al., 2015).
Akumulasi gosipol memengaruhi jumlah folikel yang sedang aktif berkembang (Gadelha et al, 2014b). Folikel primordial dan primer membutuhkan banyak nutrisi untuk melanjutkan perkembangan sehingga apapun zat yang diberikan akan memengaruhi perkembangan folikel tersebut. Gosipol bersifat sitotoksik (Randel et al, 1992) dan berkemampuan meningkatkan pembentukan reactive oxygen species (ROS) sehingga menginduksi stres oksidatif (Kovaci, 2003; Fornes et al, 1993) serta terjadi apoptosis pada folikel (Moon et al, 2011). Folikel pada masa awal perkembangan hanya dipengaruhi oleh nutrisi dan bebas dari pengaruh gonadotropin. Hal tersebut berkemungkinan menyebabkan kemunculan folikel primer menjadi lebih sedikit dibandingkan folikel sekunder dan tersier yang perkembangannya juga dipengaruhi oleh stimulasi gonadotropin (Baerwald, 2009). 
Jumlah folikel ovarium memengaruhijumlah oosit dan kompetensi perkembangan oosit (Mossa et al, 2007). Pemberian ekstrak biji kapas berkaitan dengan lingkungan folikel yang dapat memengaruhi fertilitas betina (Sirard et al, 2006). Beberapa studi menyatakan kerusakan akibat gosipol juga disebabkan oleh hambatan sekresi adrenocorticotropic hormone (ACTH), hambatan pembentukan cyclic adenosine monophosphate (cAMP) pada sel-sel luteal (Lin et al, 1994b), gangguan komunikasi interseluler (Hervé et al, 1996), gangguan metabolisme energi seluler, gangguan transpor ion melalui membran, penurunan steroidogenesis yaitu estrogen dan progesteron (Gadelha et al, 2014b).

Perubahan di dalam ovarium dipengaruhi oleh respon terhadap perubahan hormonal yang diamati dari perubahan siklus estrus. Gosipol menyebabkan pemanjangan siklus estrus dengan meningkatkan durasi fase metestrus dan diestrus (Gadelha et al, 2014a). Gambaran perbedaan siklus estrus pengamatan 24 hari dapat dilihat pada Gambar 4.

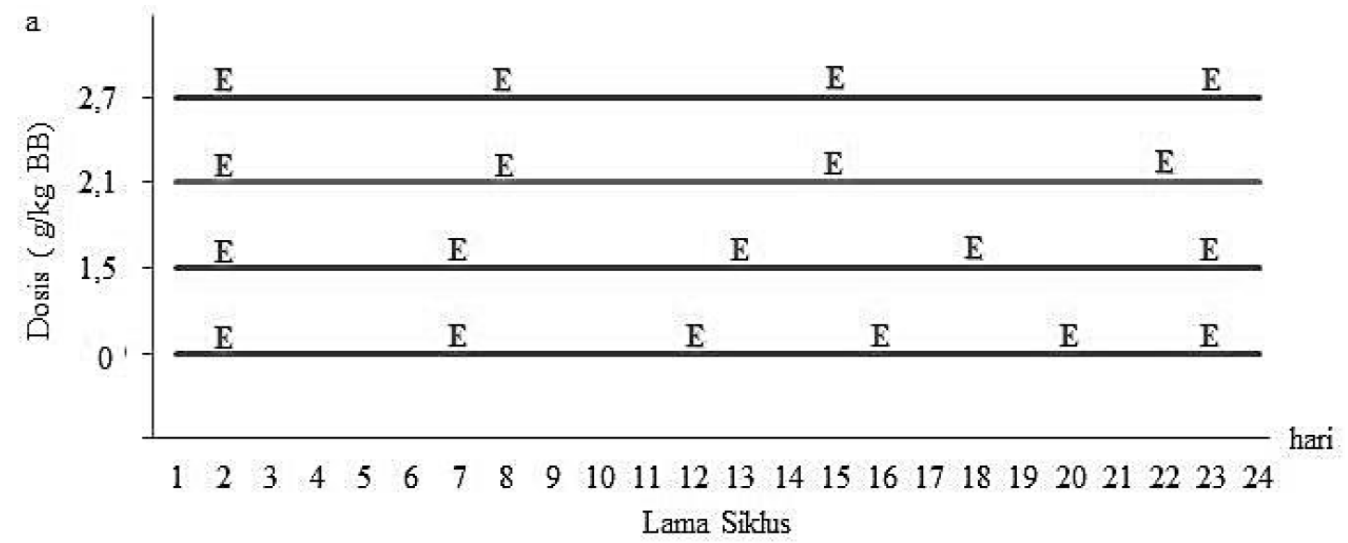

Gambar 4. a Siklus estrus mencit setelah pemberian ekstrak biji kapas selama 24 hari. b Pencapaian fase siklus estrus selama 24 hari pemberian ekstrak biji kapas.

Keterangan: $\mathrm{P}=$ proestrus, $\mathrm{E}=$ estrus, $\mathrm{M}=$ metestrus, $\mathrm{D}=$ diestrus

Hasil pemberian ekstrak biji kapas selama waktu tertentu yaitu 5, 10,15, dan 24 hari menyebabkan status reproduksi pada hari mencit dikorbankan menjadi tidak seragam. Ketidakseragaman tersebut terlihat dari perbedaan fase dalam siklus estrus yang dialami mencit. Pengamatan selama 24 hari menunjukkan bahwa secara normal mencit mengalami 6 kali estrus sedangkan mencit yang diberikan perlakuan dosis ekstrak biji kapas $1,5 \mathrm{~g} / \mathrm{kg}$ BB mengalami 5 kali estrus dan mencit yang diberikan perlakuan dosis ekstrak biji kapas 2,1 dan 2,7 g/kg BB mengalami 4 kali estrus. Gosipol menyebabkan pemanjangan siklus estrus dengan meningkatkan durasi fase metestrus dan diestrus (Gadelha et al, 2014a) sehingga durasi siklus estrus melebihi 5 hari. Pemanjangan siklus estrus menyebabkan durasi folikulogenesis menjadi lebih panjang.

\section{Kesimpulan}

Berdasarkan data yang terkompilasi dari hasil penelitian disimpulkan bahwa folikulogenesis ovarium mencit dipengaruhi oleh pemberian ekstrak biji kapas sehingga terjadi penurunan jumlah folikel berkembang dan perpanjangan durasi siklus estrus. Penurunan tersebut bersifat sementara sehingga berpotensi dapat digunakan sebagai bahan kontrasepsi. Perlu dilakukan kajian lebih lanjut 
tentang penyebab menurunnya folikulogenesis dan perpanjangan siklus estrus sehingga pemanfaatan dapat diketahui dengan lebih pasti dan luas.

\section{Daftar Pustaka}

Baerwald,A.R.(2009). Human antral folliculogenesis: what we have learned from the bovine and equine models. Anim. Reprod. 6 (1): 20-29.

Bansode, F.W. (1994). Genotoxic effects of gossypol acetate on the ovary of Rhinopoma kinneari wroughton (Microchiroptera: Mammalia). Contraception. 49 (4): 601-607.

Câmara, A.C.L., Gadelha, I.C.N., Borges, P.A.C., de Paiva, S.A., Melo, M.M. and Soto-Blanco, B. (2015). Toxicity of gossypol from cottonseed cake to sheep ovarian follicles. PloS ONE.10 (11): 1-11.

Cecconi, S. (2002). Growth and differentiation of small ovarian follicles in mammals: problems and future perspective. Reprod. Dev. 48 (5): 431-445.

Chandrashekar, R., Kumar, A.K., Reddy, Y.R., Chaitanya, P.J., Bhavani, N.L., and Pochampalli, J. (2013). Isolation of gossypol and analysis of phytochemicals in seed extract of $\mathrm{Bt}$ and non $\mathrm{Bt}$ varieties of cotton. Pharm. Phytochem. 2 (1): 1-8.

Chavatte-Palmer, P., Dupont, C., Debus, N., and Camous, S. (2014). Nutritional programming and the reproductive function of the offspring. Anim. Product. Sci. 54 (4): 1166-1176.

Fornes, M.W., Barbieri, A.M., and Burgos, M.H. (1993). Sperm motility loss induced by gossypol: relation with $\mathrm{OH}$ scavengers, motile stimulators dan malondialdehyde production. Biochem. Biophys. Res. Commun. 195 (3): 1289-1293.

Gadelha, I.C.N., Fonsesa, N.B.S., Oloris, S.C.S., Melo, M.M., and Blanco, S.B. (2014a). Gossypol toxicity from cottonseed products. Sci. World. J. 14 (4): 1-9.

Gadelha, I.C.N., de Macedo, M.F., Oloris, S.C.S., Melo, M.M., and Blanco, S.B. (2014b).
Gossypol promotes degeneration of ovarian follicle in rats. Sci. World. J. 14 (1): 1-7.

Galvao, K.N., Santos, J.E.P., Coscioni, A.C., Juchem, S.O., Chebel, R.C., Sischo, W.M., and Villasenor, M. (2006). Embryo survival from gossypol-fed heifers after transfer to lactating cows treated with human chorionic gonadotropin. Dairy. Sci. 89 (6): 2056-2064.

Hadley, M.A., Lin, Y.C., and Dym, M. (1981). Effect of gossypol on the reproductive system of male rats. Andrology. 2 (4): 190-199.

Hafez, E.S.E., and Hafez, B. (2000). Reproduction in Farm Animal. Chapter 5. $7^{\text {th }}$ ed. USA (US): Lippincot Williams and Walkins.

Hahn, D.W., Rusticus, C., Probst, A., Homm, R., and Johnson, A.N. (1981). Antifertility and endocrine activities of gossypol in rodents. Contraception. 24 (1): 97-105.

Hervé, J.C., Pluciennik, F., Bastide, B., Cronier, L., Verrecchia, F., Malassiné, A., Joffre, M., and Deleze, J. (1996). Contraceptive gossypolblocks cell-to-cell communication in human and rat cells. Eur. J. Pharmacol. 313 (3): 243-255.

Kovaci, P. (2003). Mechanism of drug and toxic action of gossypol: focus on reactive oxygen species and elektron transfer. Curr. Medicin. Chem. 10 (24): 2711-2718.

Lagerlof, R.K., and Tone, J.N. (1985). The effect of gossypol acetic acid on female reproduction. Drug. and Chem. Toxic. 8 (6): 469-482.

Leung, P.C.K., and Adashi, E.Y. (2004). The Ovary. $2^{\text {nd }}$ ed. USA (US): Elsevier Academic Pr.

Lin, Y.C., Fukaya, T., Rikihisa, Y., and Walton, A. (1985). Gossypol in female fertility control: ovum implantation and early pregnancy inhibited in rats. Life. Sci. 37 (5): 39-47.

Lin, Y.C., Coskun, S., and Sanbuissho, A. (1994a). Effect of gossypol on in vitro bovine oocyte maturation and steroidogenesis in bovine granulosa cells. Theriogenology. 41 (4): 1601-1611.

Lin, Y.C., Sanbuissho, A., Coskun, S., and Rikihisa, Y. (1994b). Inhibition of in vitro fertilization 
and early embryonic development in hamsters by gossypol. Life Sci. 55 (14): 1139-1145.

Moon, D.O., Choi, Y.H., Moon, S.K., Kim, W.J., and Kim, G.Y. (2011). Gossypol decreases tumor necrosis factor- $\alpha$-induced intercellular adhesion molecule-1 expression via suppression of NF-KB activity. Food. Chem. Toxicol. 49 (1): 999-1005.

Mossa, F., Berlinguer, F., Succu, S., Madeddu, M., Bebbere, D., Leoni, G.G., and Naitana, S. (2007). Follicle number affects in vitro developmental competence of sheep oocytes. Biol. Reprod. 2 (7): 1-7.

Myers, M., Britt, K.L., Wreford, N.G.M., Ebling, F.J.P., and Kerr, J.B. (2004). Methods for quantifying follicular numbers within the mouse ovary. Reproduction. 127(4):569-580.

Nasim, A., Schrick, F.N., Butcher, R.L., and Inskeep, E.K. (1995). Effect of persistent follicles on early embryonic losses in beef cows. Biol. Reprod. 52 (5): 1129-1135.

Paris, M.C.J., Andersen, C.Y., and Shaw, J.M. (2009). Ovarian cryopreservation and grafting: its potential for human reproductive biology and animal conservation. Anim. Reprod. 6 (1): 96-113.

Peters, H. (1969). The development of the mouse ovary from birth to maturity. Endocrinology. 62 (9): 98-116.

Randel, R.D., Chase, C.C., and Wyse, S.J. (1992). Effects of gossypol and cottonseed products on reproductive of mammals. Anim. Sci. 70 (5): 1628-1638.

Randel, R.D., Willard, S.T., Wyse, S.J., and French, L.N. (1996). Effects of diets containing free gossypol on follicular development, embryo recovery and corpus luteum function in brangus heifers treated with bFSH. Theriogenology. 45 (6): 911-922.

Scudamore, C.L. (2014). Histology of the Mouse. England (UK): John Wiley and Son.

Senger, P.L. (2005). Pathways to Pregnancy and Parturition second revised edition. Washington (US): Current Conception, Inc.

Silber, S. (2015). Unifying theory of adult resting follicle recruitment and fetal oocyte arrest. Reprod. Biomed. Online. 31 (5): 472-475.

Singla, N., and Garg, M. (2013). Effect of crude cottonseed oil containing gossypol on fertility of male and estrous cycle of female Bandicota bengalensis Gray and Hardwicke. Appl. Anim. Res. 41 (2): 156-165.

Sirard, M.A., Richard, F., Blondin, P., and Robert, C. (2006). Contribution of the oocyte to embryo quality. Theriogenology. 65 (6): 126-136.

Webb, R., Nicholas, B., Gong, J.G., Campbell, B.K., Gutierrez, C.G., Garverick HA, and Armsrong DG. (2003). Mechanisms regulating follicular development and selection of the dominant follicle. Reproduction. 61 (3): 71-90.

White, I.G., Vishwanath R, Swan MA, BrownWoodman PD. 1988. Studies of the mechanism of action of gossypol as a male antifertility agent. Contraception. 37 (3): 1-8.

Woodruff, T.K., and Shea, L.D. (2011). Anew hypothesis regarding ovarian follicle development: ovarian rigidity as a regulator of selection and health. Assist. Reprod. Genet. 28 (1): 3-6. 